Nova Biologica Reperta 6(3): 347-351 (2019)

Print ISSN: 2423-6330/Online ISSN: 2476-7115

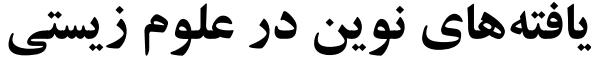

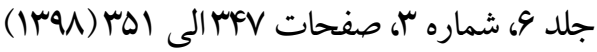

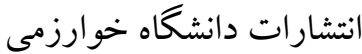
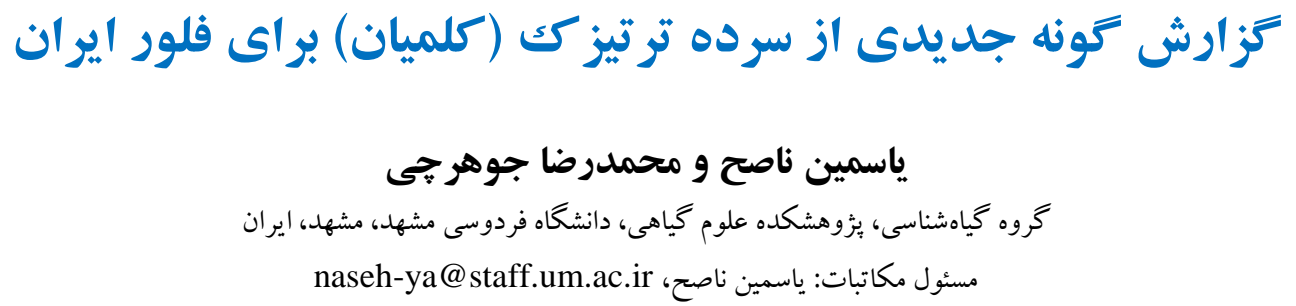

جكيده. در اين بررسى آرايهاى جديد تحت عنوان Lepidium ferganense (تيره كلميان) براى نخستين بار براى فلور ايران گزارش مىشود. اين آرايه متعلق به

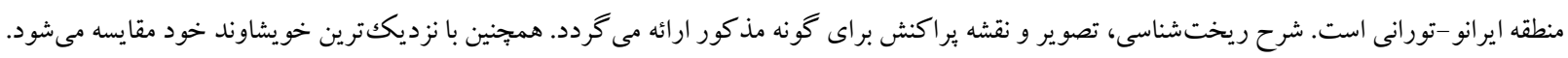
وازههاى كليدى. ايرانو -تورانى، استان خر اسان رضوى، شمال شرقى ايران، شرح ريختشناختى

\title{
A new record of Lepidium (Brassicaceae) for the flora of Iran
}

\author{
Yasamin Nasseh \& Mohammad Reza Joharchi \\ Research Center for Plant Sciences, Ferdowsi University of Mashhad, Iran \\ Correspondent author: Yasamin Nasseh, naseh-ya@staff.um.ac.ir
}

\begin{abstract}
In this paper, the new taxa Lepidium ferganense (Brassicaceae) was recorded for the flora of Iran for the first time. This taxon belongs to Irano-Turanian region. It was compared with the closest taxa in the present study. In addition, a morphological description, several Illustrations, and a distribution map were presented.
\end{abstract}

Keywords. Irano-Turanian, NE Iran, Morphological description, Razavi Khorassan province 


\section{INTRODUCTION}

Lepidium $\mathrm{L}$. is one of the five largest genera of the Brassicaceae with ca. 260 species in the world (AlShehbaz et al., 2006). There are 16 species of this genus in Iran (Fakhr Ranjbari, 2017). The distribution areas of the species of this genus are mostly Central, Middle and South West Asia (German, 2014). In this genus, a tendency for some of the flower parts was observed to be reduced to the point of absence, therefore, flower structure is used in subgeneric classification (Hewson, 1981; Bona, 2012). Fruit and seed characters are also valuable. However, the latter tends to have been ignored in Lepidium. The characters of vegetative morphology are often used as species-defining characters (Hewson, 1981; Bona, 2012). There are 18 species of the genus Lepidium s.l. in Iran, two of which have been reported recently (Al-shehbaz, 2017; Mamizadeh \& Naqinejad, 2018).

During the study on Lepidium persicum Boiss., specimens collected from NE Iran and deposited in Ferdowsi University of Mashhad Herbarium (FUMH) were invistigated. It was found that a specimen is different in some characteristics from individuals belonging to L. persicum. After reviewing and comparing the morphological traits, we came to the conclusion that the specimen belongs to $L$. ferganense Korsh. The species was originally introduced from Central Asia, Fergana (Uzbekistan). This is the first record of this species from Iran. The main morphological features of this taxon are flaccid to ascendence pedicel, oblong-lanceolate stem leaves or leafless and wingless seeds.

\section{MATERIALS AND METHODS}

The present study was performed to evaluate the specimens collected from NE Iran and preserved in Ferdowsi University of Mashhad Herbarium (FUMH). Non-determined herbarium specimens of the genus Lepidium have been studied. These specimens were morphologically studied based on available literature (Busch, 1939; Vassilczenko, 1948; Hedge, 1968; Junussov, 1978; Hewson, 1981; Zhou et al. 2001; Bona, 2012; Al-Shehbaz, 2012; German, 2014). Also, we studied photographs available in JSTOR global plants (http://plants.jstor.org) and Virtual Herbaria (http://herbarium.univie.ac.at/database /index.php).

The Illustration of the new record was presented and the distribution map of the species in Iran was provided using ARC-GIS (Esri, 2011).

\section{RESULTS AND DISCUSSION Taxonomic treatment}

\section{New records}

-Lepidium ferganense Korsh. (1898), Flora of Turkestan (1898: 417). Fig. 1, 2.

$=$ L. persicum subsp. arianum Hedge; Fl. Iranica. 57: 343 Addena (1968).

$=$ L. seravschanicum Ovcz. \& Junussov in Junussov (1978: 628).

Distribution: Afghanistan, Iran, Kazakhstan, Kyrgyzstan, Tajikistan, Uzbekistan, and Xinjiang.

Description: Perennial herbs, (25-) 35-100 (-110) $\mathrm{cm}$ tall. Stems simple, few from base, many branched above, glabrous. Basal and lower cauline leaves long petiolate, papery; leaf blades linearlanceolate or linear-oblong, (2-) 3-12 (-14) $\times(0.3-)$ 1-2.5 (-4) cm, base cuneate or attenuate, margin serrate, apex often acute. Upper cauline leaves shortly petiolate; leaf blades linear, (1-) 2-8 (-10) cm $\times(1-)$ 2-7 (-10) $\mathrm{mm}$, base attenuate or cuneate, margin entire, apex acute. Fruit stalks (3-) 4-5 (-6) $\mathrm{mm}$, slender, divaricate. Sepals deciduous, ovate, 1$1.5 \times 0.8-0.9 \mathrm{~mm}$, glabrous, white at margin and apex. Petals white, broadly obovate, (2-) 2.5-3 × 1$1.4 \mathrm{~mm}$, apex rounded; claw 0.7-1 mm. Stamens 6; filaments $0.9-1.3 \mathrm{~mm}$; anthers ovate, $0.2-0.3 \mathrm{~mm}$. Fruits ovate-oblong or suborbicular, 2.5-3.5 × 2-2.5 $\mathrm{mm}$, glabrous, wingless, carinate at replum, base rounded; apical notch absent or obsolete; style obsolete or rarely to $0.1 \mathrm{~mm}$; stigma wider than style. Seeds reddish brown, oblong, 1.5-2.2 $\times 0.7$ $1.2 \mathrm{~mm}$, often 3-angled, wingless, finely papillate.

Flowering and fruiting: June-August.

Habit and Ecology: Dry mountain slopes; 1870$1900 \mathrm{~m}$.

Specimen seen: Iran, Razavi Khorassan province, $\mathrm{N}$ Kashmar, Ili pass, $3 \mathrm{~km}$ of Chelpo, 1870-1900 m, N: $35^{\circ} 37^{\prime} 10$. 4", E: $58^{\circ} 30^{\prime} 33.6^{\prime \prime}, 22.5 .2007$, Memariani \& Zangooei 38929.

Note: L. persicum subsp. arianum has been considered to be a new synonym for $L$. ferganense and this synonymization, with regard to the L. ferganense, with highly variable features and wide distribution in neighboring Middle Asian mountains, is obviously unavoidable (German, 2014). The features attributed to the $L$. persicum and $L$. ferganense were compared in Table 1.

The identification key for the perennial species of Lepidium thriving in Iran, on the basis of prominent morphological features, is presented here. 


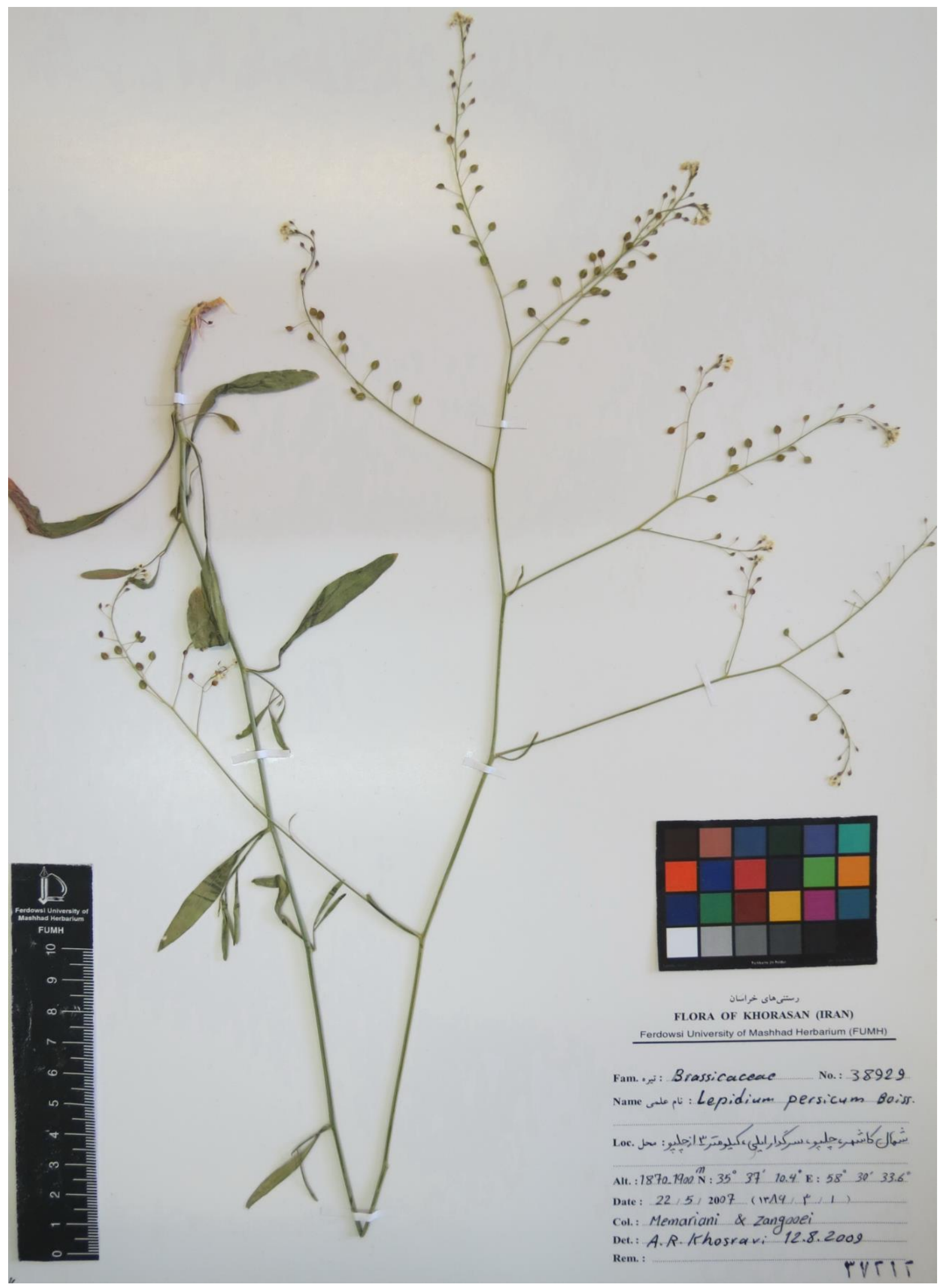

Fig. 1. Lepidium ferganense Korsh.; Memariani \& Zangooei 38929 (FUMH). 


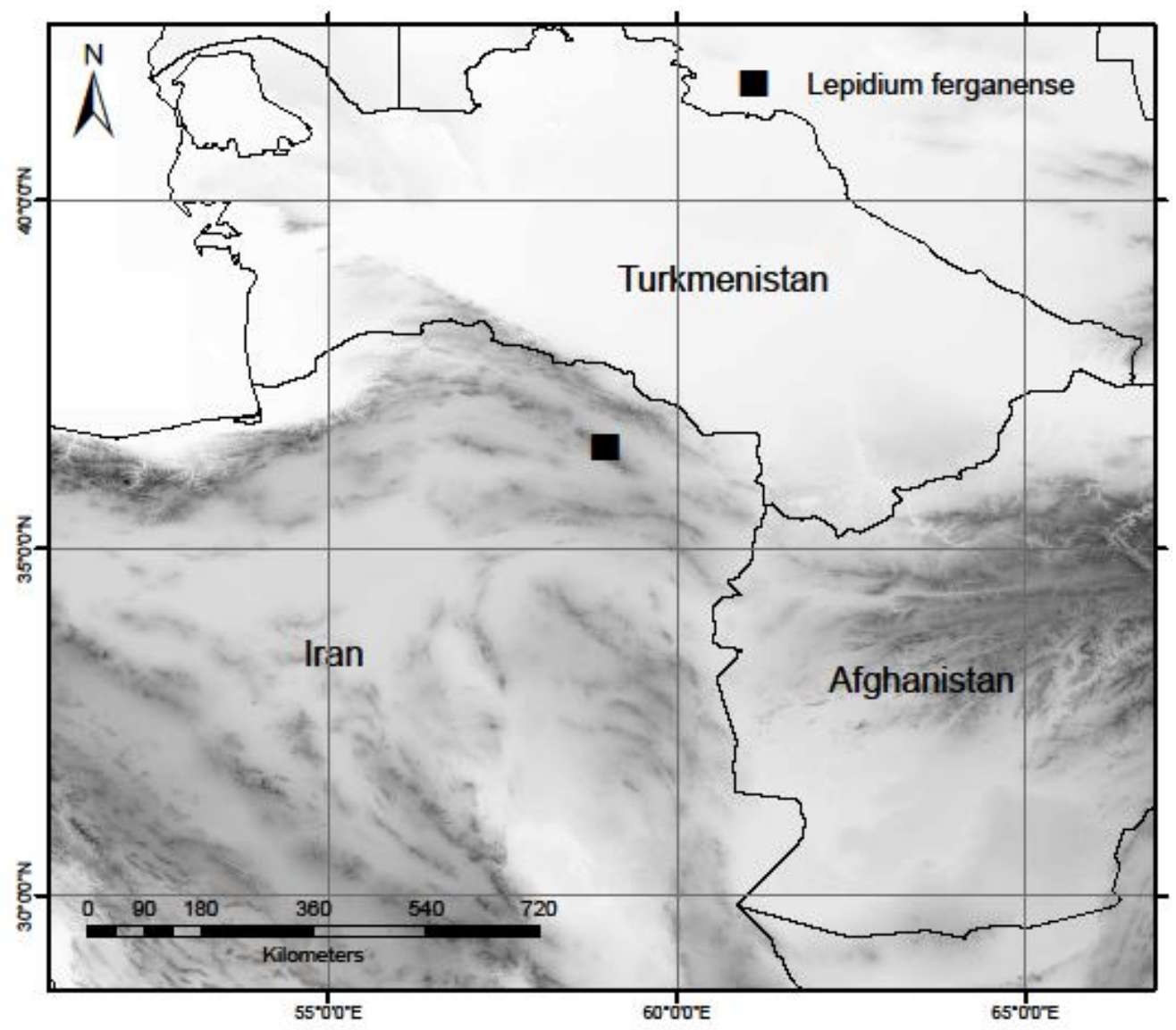

Fig. 2. Distribution map of Lepidium ferganense Korsh.

Table 1. Comparison of the characteristics between Lepidium persicum and L. ferganense

Species

Characters

Stem leaves

Pedicel when fruiting

Seeds
Oblong-lanceolate

L. ferganense

Flaccid patule, ascendense, 4-6 mm long

Wingless
L. persicum

Linear- oblong

Rigid erect or patule, 1-4 (-5) mmlong,

Winged or wingless
Identification key for perennials Lepidium species in Iran

1. Plants with orbicular and plump fruits. $\ldots . .2$

- Plants with flattened fruits.........................6 6

2. Plants with stoloniferous stems, without fibrous strands at base; fruits orbicular or ovate, twin in ripening, truncate or cordate at base, indehiscent ..L. draba

- Plants without stoloniferous stems, without fibrous strands remains of leaves from years ago at base; fruits dehiscent.

.... 3

3. Stem leaves sessile, amplexicaul.......L. litwinowii

- Stem leaves petiolate, non amplexicaul.

4. Silicles obovate to ovate, 7-9 mm long; style ca. 1 mm long... L. longifolium
- Silicle ovate or elliptic, less than $7 \mathrm{~mm}$ long; style less than $1 \mathrm{~mm}$ long............................. 5 5. Basal leaves lanceolate-linear, up to $0.8 \mathrm{~cm}$ width, middle leaves linar to linear-lanceolate, small numbers. .L. affghanum -Basal leaves lanceolate, 3-4 cm width, middle leaves spatulate or oblanceolate, large numbers...... ..L. buschianum 6. Plants with clavate hairs; ripe silicle prominently reticulated on surface....................cartilagineum - Plants glabrous or without clavate hairs; ripe silicle glabrous....................................... 7 7. Uppermost cauline leaves sessile or subsessile, leathery; fruit not carinate, seeds 1-1.3 mm long .L. latifolium 
- Uppermost cauline leaves papery; fruit carinate, seeds $1.5-2.2 \mathrm{~mm}$ .8

8. Stem leaves linear-oblong, pedicel when fruiting rigid erect or patule, 1-4 (-5) $\mathrm{mm}$ long; seeds winged L. persicum

- Stem leaves linear-oblong, pedicel when fruiting flaccid patule, ascendense, 4-6 $\mathrm{mm}$ long; seeds wingless or winged L. ferganense

\section{ACKNOWLEDGMENT}

We are thankful to Mr. Hamid Reza Sharghi (Ferdowsi University of Mashhad) for preparing the photographs and we also offer our special thanks to Ms. Maryam Behroozian who helped us with the preparation of the distribution map.

\section{REFERANCES}

Al-Shehbaz, I.A., Beilstein M.A. and Kellogg EA. 2006. Systematic and phylogeny of the Brassicaceae (Cruciferae): an overview. - Plant Syst. Evol. 259: 89-120.

Al-Shehbaz, I.A. 2012. A generic and tribal synopsis of the Brassicaceae (Cruciferae) - Taxon 61: 931-954.

Al-Shehbaz, I.A. 2017. Five New Species of Lepidium (Brassicaceae): L. pabotii (Iran), L. arequipa (Peru), and L. lapazianum, L. linearilobum, and L. stephanbeckii (Bolivia). - Novon 25: 403-413.

Boissier, E. 1843. Diagnosis. Plantarum Orientalium Novarum, ser. 1, No. 2, Lipisiae \& Lipsiae \& Parisiis, Genevae, $115 \mathrm{pp}$.

Bona, M. 2012. Distribution of Lepidium taxa in Turkey. - Bocconea 24: 221-225.
Busch, N.A. 1939. Cruciferae B. Juss. - In: Komarov, V.L. (ed.) Flora of USSR 8: 14-606. - Editio Academiae Scientarum USSR, Moscow \& Leningrad.

Esri. 2011. ARC-GIS Desktop. Release 10. Redlands, CA: Environmental Systems Research Institute.

Fakhr Rangbari, H. 2017. Tribe: Lepidieae. - In: Assadi et al., M. (ed.), Flora of Iran: Brassicaceae, 143: 102137. - RIFR, Tehran.

German, D.A. 2014. Taxonomic remarks on some Asian Lepidium s.1. (Brassicaceae). - Phytotaxa: 186: 97105.

Hedge, I. 1968. Tribus Lepidieae. - In: Rechinger, K.H. (ed.) Flora Iranica 57: 63-122. - Akademische Drucku. Verlagsanstalt, Graz.

Hewson, J. 1981. The genus Lepidium L. (Brassicaceae). - Australia Brunonia 4: 217-308.

Junussov, S.Yu. 1978. Lepidium L. - In: Ovczinnikov, P.N. (ed.) Flora Tadzhikskoǐ SSR [Flora of Tajik SSR] 5: 233-243, 628. - Nauka, Leningrad.

Mamizadeh, L. and Naqinejad, A.L. 2018 Lepidium virginicum L. (Brassicaceae) a new record for the flora of Iran. - Nova Biol. Reperta 5: 324-328.

Vassilczenko, I.T. 1948. Cruciferae. - In: Shishkin, B.K. \& Vassilczenko, I.T. (eds.) Flora Turkmenii [Flora of Turkmenistan] 3: 169-268. - Publishers of Turkmenian Branch of Academy of Sciences of USSR, Ashgabad.

Zhou, T.-Y., Lu L.-L., Yang G. and Al-Shehbaz, I.A. 2001. Brassicaceae (Cruciferae). - In: Wu, Z.-G. and Raven, P.H. (eds.). Flora of China 8: 1-193. (Brassicaceae through Saxifragaceae). - Science Press, Beijing, and Missouri Botanical Garden Press, St. Louis.

How to cite this article:

Nasseh, Y and Joharchi, M.R. 2019. A new record of Lepidium (Brassicaceae) for the Flora of Iran. - Nova Biol. Reperta 6: 347-351 